\title{
Beyond Spiritual Focus: Climate Change Awareness, Role Perception, and Action among Church Leaders in Nigeria
}

\author{
GEORGE C. NCHE \\ Department of Religion Studies, University of Johannesburg, Johannesburg, South Africa
}

(Manuscript received 13 January 2019, in final form 20 November 2019)

\begin{abstract}
This study explored the role of church leaders in addressing climate change with a focus on Catholic, Anglican, and Pentecostal churches in Nigeria. The study adopted a semistructured face-to-face interview with 30 church leaders drawn from the selected denominations (i.e., 10 church leaders from each denomination). These participants were spread across five states in five geopolitical zones in Nigeria. A descriptive narrative approach was employed in the thematic organization and analysis of data. Findings showed that while all the participants across the three denominations-Catholic, Anglican, and Pentecostal churches-agreed to have heard of climate change, their perceptions of the causes of the phenomenon were narrow and varied along religious denominational lines. More Catholic participants expressed belief in anthropogenic climate change than did Anglicans and Pentecostals. Awareness creation, charity for disaster victims, and prayer were identified by the participants as the roles churches can play in addressing climate change. Although climate change action was generally poor among participants, Catholics engaged more in organizational action than did Anglicans and Pentecostals. In contrast, climate change actions were more on a personal level than on the organizational/church level within Pentecostal churches. The implications of the findings for the Church/church leaders, policy, and future research are discussed.
\end{abstract}

\section{Introduction}

Developing countries in Africa, including Nigeria, are particularly vulnerable to the impacts of climate change (IPCC 2014; Niang et al. 2014; Serdeczny et al. 2016). It has been projected that climate change will undermine development efforts in Africa and will hit the poorest and most vulnerable sections of the society such as agriculture, water, energy, health, wildlife, and tourism (Madzwamuse 2010; NEST 2011). This is as a result of the "limited adaptive capacity" (Ojomo et al. 2015 , p. 436) or the socioeconomic, political, and cultural conditions in these countries.

In Nigeria, the issue of vulnerability to climate change is experiential as several communities along the different eco-zones (coastal, savannah, and Sahel eco-zones) have already started suffering the severity of climate change impacts. These impacts come in different forms and have affected virtually all aspects of the country's life-agriculture, health and sanitation, livelihood, energy, infrastructure, human settlements, and housing, etc. (see Ebele and Emodi 2016; Ajaero et al. 2009; BNRCC 2011;

Corresponding author: George C. Nche, nche.george@unn.edu.ng
NEST and Woodley 2012; Onwuka et al. 2015). For instance, while narrating the gory tales of the year 2012 flood, which has been adjudged the worst in the past 40 years in Nigeria (Ajaero et al. 2016), Akpoborie (2012) as cited in Nche et al. (2017, p. 2) wrote,

From Cross River, Akwa Ibom, Rivers, Bayelsa, Delta, Anambra, Imo through Edo to Niger, Benue, Taraba, Jigawa, Platuea and Kogi States, come accounts of woe, death and destruction of homes, public buildings, roads, bridges, public utilities, crops, livestock and farms. Hundreds of thousands of hectares of farms have been swept away (about 400,000 hectares in Jigawa State alone) while millions of people who have lost everything to the floods are being accommodated in temporary camps scattered all over the country. An untold number are harbouring with relations. Stories of suicide by farmers who took loans from banks and lost everything to the floods abound.

In 2018, Nigeria experienced flood disasters affecting 12 states and 327000 people, as well as $>150000$ ha of farmland across the states (Leadership 2018). Yet, scientists have, on the platform of the Intergovernmental Panel on Climate Change (IPCC), warned that more severe impacts await many societies, especially developing ones, 
if nothing substantial is done about climate change (Romm 2016). In fact, the UNFCCC in Nairobi has particularly warned that one day, the city of Lagos with about 7-14 million inhabitants might sink completely into the sea (Nche et al. 2017). On the other hand, the U.S. National Aeronautics and Space Administration has warned that Lake Chad is slowly being transformed into a desert landscape. It was said to be about the size of Lake Erie in the mid-1960s. However, the persistent drought conditions, added to increased demand for freshwater for irrigation, have reduced Lake Chad to about $5 \%$ of its former size (Leadership 2018; Oyedele 2017).

These impacts make climate change mitigation and adaptation imperative in Nigeria. It is thus crucial that citizens, especially stakeholders, are knowledgeable about climate change and its impacts as well as active in climate change mitigation and adaptation campaigns in the country. In this light, this study explored the role of church leaders in addressing climate change with a focus on Catholic, Anglican, and Pentecostal churches in Nigeria. Specifically, the study examined the awareness/knowledge of climate change among these leaders, their views on the role of the church, and what they have done or the extent they have gone in addressing climate change through proenvironmental behaviors or actions. Previous studies have primarily focused on ascertaining climate change awareness/knowledge, perceptions and adaptation strategies among students/graduates (i.e., secondary school and university students/graduates) (see Oruonye 2011; Ayanlade and Jegede 2016), ministry of environment workers (Ojomo et al. 2015), farmers (see Ofuoku 2011; Adebayoet al. 2012; Idrisa et al. 2012; Farauta et al. 2012; Nzeadibe et al. 2012; Ismail 2014; Agu et al. 2015; Ayanlade et al. 2017), and insurers (Elum and Simonyan 2016) in Nigeria. Only one known study has focused on religious leaders in Nigeria (see Shehu and Molyneux-Hodgson 2014) yet with a limited focus on Christian and Muslim leaders in the northeastern part of the country. However, with its focus only on Christian leaders, the present study broadened the scope of participants to include church leaders drawn from different denominations and geopolitical zones in Nigeria. This was necessary to allow for more robust information across denominations and geographical areas on the phenomenon of climate change. Also, unlike the Shehu and Molyneux-Hodgson's study whose focus was limited to the clergy and clerics, the present study broadened its focus to include both clergy and lay leaders. This is due to the fact that lay leaders, like the clergy, also wield influence in churches especially within the groups they lead.

\section{Why church leaders?}

The remedy to the global ecological crisis that has climate change at its vanguard seems to have practically evaded the grip of laws and policies as arguably seen in the failure or the highly "politicized" reports of the several United Nations climate change conferences starting from the Conference of the Parties 1 (COP 1) held in Berlin, Germany, in 1995 through to the recently concluded COP 21/CMP 11 held in Paris, France, in 2015 (Rudd 2015). For instance, the International Energy Agency's (IEA) annual survey of global carbon levels showed an overall increase in $\mathrm{CO}_{2}$ emissions a year after the signing of the Paris Climate Agreement. In 2017, energy-related emissions increased by $1.4 \%$, equivalent to adding 170 million cars to the road (Storrow 2018). Despite environmentalists' best efforts, the necessary political will and public engagement to fuel robust action on climate change remain in short supply (Wilkinson 2012). Little wonder, then, that many observers have criticized the global political response to climate change, which largely seeks to institutionalize scientific solutions to contemporary environmental problems (see Fromming and Reichel 2012; Gerten 2010; Moore and Nelson 2010).

Hence, engaging the deeply held values and beliefs that both interpret and filter people's perceptions as well as lead to and inspire direct action becomes a veritable option for remedy (Mastaler 2014; Shehu and Molyneux-Hodgson 2014). Nasr (1967) observes that the ecological crisis is fundamentally a crisis of values and that religions being the primary sources of values in any culture are hereby implicated in the decisions humans make regarding the environment. In this light, it has been suggested that the practical involvement of religion in tackling the global ecological crisis especially the challenge of climate change mitigation and adaptation may yield desired results (Corner 2013; Coward and Hurka 1993; Mastaler 2014; Millais 2006; Nche 2012; Posas 2007; Stults 2006; Tucker and Grim 2001). This is largely because organized religions have fundamentally shaped human cultural and ethical values around the world (Kaplan 2010). Faith communities, therefore, have spiritual resources or the unique ability to construct moral frameworks that can encourage human beings to protect Earth (Bomberg and Hague 2018; Morrison et al. 2015; Tarakeshwar et al. 2001; Tucker 2003).

To achieve this, the leaderships of these faith communities may be indispensable. In fact, the clergy and religious leaders have been found to be particularly influential in shaping the environmental worldviews of their congregations (Djupe and Hunt 2009; Mastaler 2014; 
Simkins 2008a,b). Also, in recent times, there has been increasing emphasis on the role of religious leaders in the fight against climate change in Nigeria (Nche et al. 2017; Thomas-Odia 2018; Aliyu 2018). Yet, not many studies have examined the roles of Church leaders in addressing climate change. It is in this light that this study focused on the role of Catholic, Anglican, and Pentecostal church leaders in addressing climate change in Nigeria.

The leadership of Catholicism, Anglicanism, and Pentecostalism are critical in Nigeria's Christianity. With congregations that constitute the major proportion of Nigeria's Christian population of about 8.5 million (Pew Research Center 2011), they wield significant influences in the country. Evidence abounds of some sociopolitical and economic interventions by these church leaders that proved productive and fruitful in the country. For instance, through several platforms such as the Christian Association of Nigeria (CAN), the Pentecostal Fellowship of Nigeria (PFN), and the Catholic Bishops Conference of Nigeria ( $\mathrm{CBCN})$, these church leaders have intervened or expressed views on issues concerning good governance (see Joshua 2015; Guardian 2015a), gender equality (NPRC 2010), education (see CBCN 2014; Obasanjo 2009; Oyediran 2017), health (see CBCN 2017a; Makinwa 2016; Nwankwo 2015; Okpalike and Nwadialor 2015; Oluwabamide and Umoh 2011; Scott-Emuakpor 2010), and terrorism (see Thomas 2013; Binniyat et al. 2017) in Nigeria. All these suggest that church leaders not only wield influence within their churches, but they also have and display critical stakes in socioeconomic and political affairs in Nigeria. This further lays credence to the focus of this study.

\section{Methods}

\section{a. The study locations/areas}

The six geopolitical zones formed the clusters into which the researchers divided Nigeria. With the exception of Northeast (Adamawa, Bauchi, Borno, Gombe, Taraba, and Yobe States) on the basis of security challenges, the researcher listed all of the states in these respective geopolitical zones in an alphabetical order. These geopolitical zones alongside their states include South-South (Akwa Ibom, Bayelsa, Cross River, Delta, Edo, and Rivers States), Southeast (Abia, Anambra, Ebonyi, Enugu, and Imo States), Southwest (Ekiti, Lagos, Ogun, Ondo, Osun, and Oyo States), North central [Abuja (the Federal Capital Territory), Benue, Kogi, Kwara, Nassarawa, Niger, and Plateau States], and Northwest (Jigawa, Kaduna, Kano, Katsina, Kebbi, Sokoto, and Zamfara States).

The third state in each of these geopolitical zones was selected using systematic sampling technique. In this sense, the selected states included Cross River, Ebonyi, Kano, Kogi, and Ogun States. Then, the capital cities in these selected states were purposively selected for the study. This is because of the complexity of the phenomenon under study, which requires a more educated population of participants in the cities or urban areas. This, however, did not apply to Kano State where most of the local government areas are dominated by Muslims, except for the Sabon-garri area where foreigners and mostly Christians reside in the state. Hence, the researcher randomly selected churches in the Christian-dominated Sabon-garri area in Kano State. The selected capital cities in the other four states accordingly included Abakaliki (Ebonyi State), Abeokuta (Ogun State), Calabar (Cross River State), and Lokoja (Kogi State). The specific locations of churches within the selected cities were randomly selected.

\section{b. Participants recruitment}

The study involved 30 church leaders of the selected churches/denominations (i.e., 10 Catholics, 10 Anglicans, and 10 Pentecostals) in the respective selected states in Nigeria. The age of the participants ranged from 26 to 52, with a mean age of 40.6. Twenty-six of the participants are male. The researcher selected two persons from each of the three churches/denominations in each of the geopolitical zones (totaling six participants from each zone) using a snowball or referral sampling technique reflecting people's social networks (see Singleton and Straits 1999) (Table 1).

In this technique, participants are asked to identify and contact others who meet specified research eligibility criteria (Babbie 2011). The criteria for selecting the participants included 1) being either the priest/chaplain/pastor or a lay person occupying a leadership position in the church, 2) being a full member of the church (i.e., baptized member who receives communion) especially for lay leaders, 3) being an adult aged 18 or above, and 4) residing in any of the capital cities in the selected states. Participant recruitment materials such as an informed consent form and the referral form were developed. The informed consent form states that the participants are guaranteed certain rights, agreed to be involved in the study, and acknowledged their rights are protected, while the referral form basically requires the participants to refer the researchers to other qualified participants. The researcher also contacted clergy and lay leaders either through direct, face-to-face contact, or telephone calls to ask about their willingness to participate, and to inform or refer the researcher to interested, qualified potential participants. 


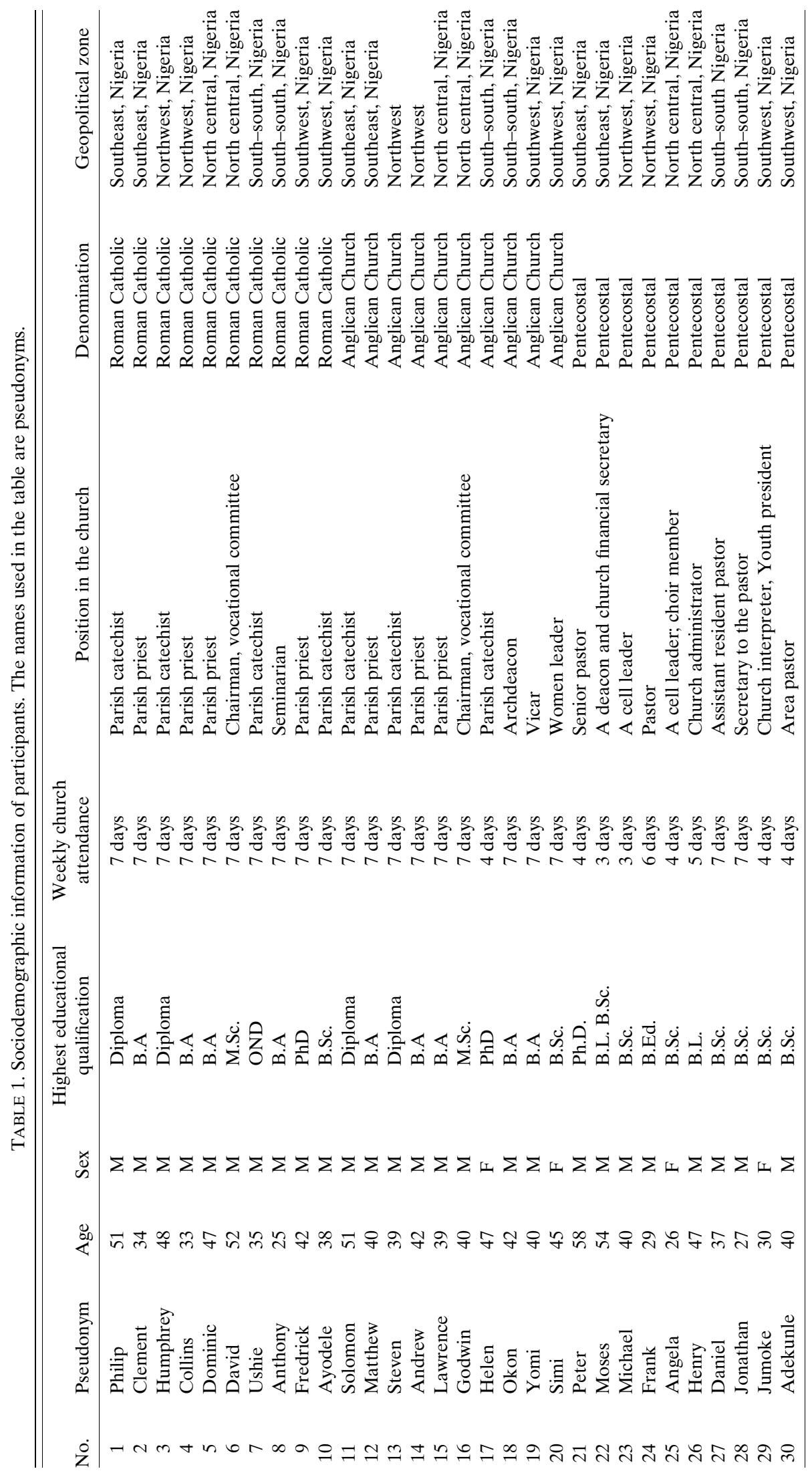


The researcher participated in Sunday services (e.g., at Anglican Church, Satellite Town, Calabar; Saints Michael, Gabriel and Raphael Catholic Church, Lokoja; Christ Embassy, Kano; All Saints Anglican Church, Abakaliki; Assemblies of God Church, Abakaliki), weekday fellowships (e.g., at Winners Chapel, Calabar), and prayer meetings (e.g., at Winner Chapel, Lokoja-although I did not succeed in securing an interview with the pastor or assistant pastors, I eventually succeeded in securing interviews at the Charismatic Renewal Ministry, Lokoja) as part of the search for participants.

\section{c. Data collection}

As has been noted earlier, the primary technique for the collection of data for this study was conducting indepth semistructured face-to-face interviews, except in the case of six church leaders in Abeokuta, Ogun State, who were interviewed over the telephone. This exception became necessary because the researcher could no longer embark on further travels because of financial constraints. Yet, there was not much discernible deficiency because all of the interview questions were exhaustively attended to and audio recorded throughout the telephone conversations. The interview protocol (see Table A1 in the appendix), apart from the one seeking sociodemographic information, included basically five open-ended questions. These questions focused on the major themes or subject matter of the study: awareness/knowledge of climate change, perceptions of churches' role in addressing the phenomenon, and climate change action among church leaders in Nigeria. These questions were drafted following an interview guide prepared by the researcher. With one or two questions addressing each of these subject matters, the interview protocol was carefully verified and validated.

If participants did not change the sequence of subjects of discussion, interviews generally followed a three-part topical order. The first focused on ascertaining whether the participants are aware of climate change. And if they are aware, the researcher inquired about their knowledge or in-depth understanding of what climate change really is, in relation to its causes and effects. However, in cases in which participants expressed lack of awareness of climate change, the researcher drew their attention to some climate change-induced disasters, such as flood and drought, in order to know their opinions about them. The second part focused on examining the perceptions of participants about churches' role in addressing the phenomenon. The third and final part focused on knowing whether participants engage in any proenvironmental behaviors to address climate change. The interviews were digitally audio recorded and varied in length of time depending on the participants' nature and disposition. All interviews were conducted in English.

\section{d. Data analysis}

The researcher adopted a descriptive narrative approach in the thematic analysis of the data. Relying on Colaizzi's (1978) guide (as cited in Sanders 2003; Speziale and Carpenter 2007; Shosha 2010) the following steps were taken in the process of the data analysis:

1) Each interview audio recording was carefully transcribed by the researcher. Each of the transcripts was painstakingly verified afterward by the researcher who listened to each interview audio recording to ensure accuracy.

2) Each transcript was read and reread to obtain a general sense about the whole content.

3) For each transcript, significant statements that pertain to the phenomenon under study were extracted. These statements were written on a separate sheet, noting their pages and line numbers.

4) Meanings were formulated from these significant statements in line with the major objectives of the study, which are climate change awareness/knowledge, churches' role perceptions, and climate change action.

5) The formulated meanings were sorted into categories and clusters of subthemes under the aforementioned major objectives.

6) The findings of the study were then integrated into an exhaustive description of the phenomenon under study, which is climate change awareness/knowledge, role perception, and action.

\section{Results and discussion}

All the participants across the three denominationsCatholic, Anglican, and Pentecostal-agreed to have heard of climate change. However, their responses to questions bordering on the definition/conceptualization of climate change with respect to its causes and effects, church's role perception, and action informed the following themes and subthemes (Fig. 1).

\section{a. Awareness/knowledge of climate change}

\section{1) CAuses of Climate change}

The study found that a majority of the participants say that climate change is caused by human activity (i.e., anthropogenic climate change) although some have inaccurate information about which human activities contribute to climate change (see Table 2). 


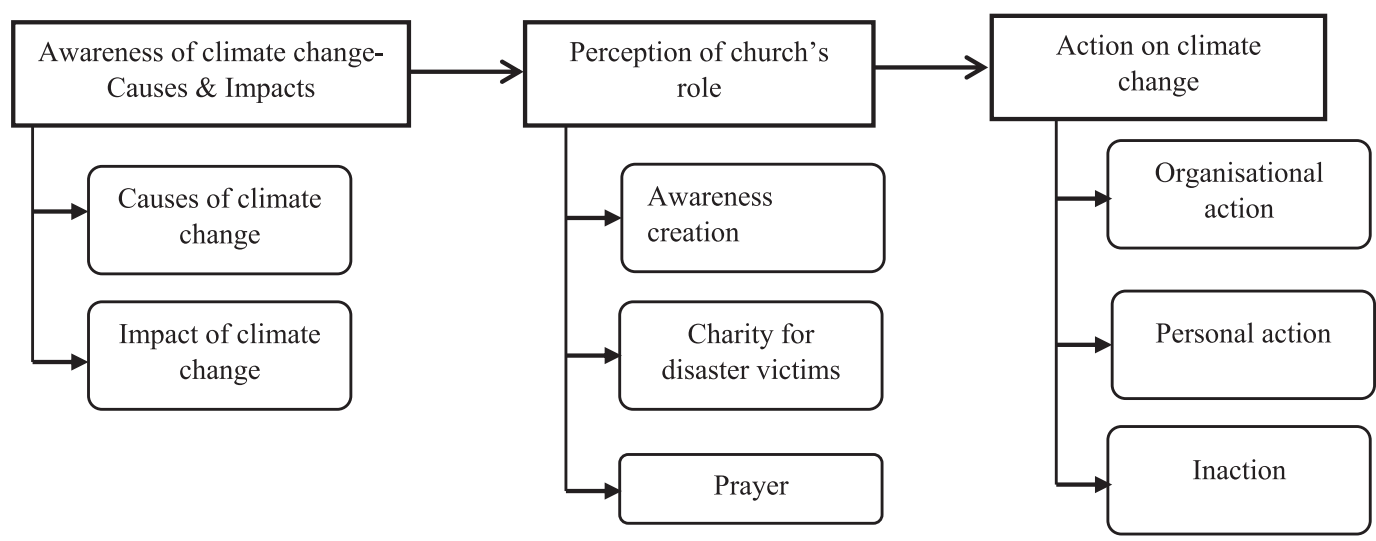

FIG. 1. Summative presentation of themes and subthemes.

For instance, when asked about the major causes of climate change, Michael of Christ Embassy, Kano, responds "definitely, human activities contribute much to climate change." Explaining further how human activities contribute to climate change, Michael says,

The release of gas into the atmosphere...affects the ozone layer (in) such a way that...there is not much penetration because of the gas disposition (in) the air, and again the trees, most times that people cut trees to make firewood, ...the discharge of the smoke also contribute, and you know, when there are more trees, they release, there is what we call, is it, transpiration, whereby the release (of) vapour increases humidity which also increases rain. But the more trees you cut down, it also affect the humidity range.

Also, sharing the same view, was Moses, a deacon in Assemblies of God, Abakaliki, who maintains that manmade desertification occasioned by overgrazing on land as well as "cutting of woods in the forest" are among the major causes of climate change. Furthermore, things like human-run factories that emit toxic fumes into the atmosphere are, according to Dominic, affecting the ozone layer.

This finding is consistent with the findings of Ayanlade and Jegede (2016) and Ojomo et al. (2015) studies. These studies found that a majority of students and government workers (i.e., $80 \%$ and $90 \%$, respectively) believe in anthropogenic climate change. This suggests that some sets of Nigerians are becoming aware of the major scientifically proven causes of climate change, albeit with little or no detailed understanding of how it works. This awareness is relevant for climate change mitigation in the country. Even though awareness does not always translate to action, Stehr and Grundmann (2012) note that awareness "should be understood as the first step towards action."

However, there were other participants in the current study who were not able to identify the causes of climate change. Some were of the opinion that climate change is naturally caused. For instance, according to Humphrey, a catechist from Kano, climate change refers to seasonal variations due to certain natural phenomenon. When asked whether he believes that climate change is naturally caused, Humphrey responds "that is what I believe, it is natural, it is natural, it is natural." However, he does not completely write off the impact of human activities. For him, while there are some human activities such as "felling of trees" that contribute to climate change, the natural causes are beyond the human contributions. This is also shared by Jonathan of Winners Chapel, Calabar. According to him, since climate change is a natural disaster, nature is the major cause, as "it is bound to occur" independent of human activities. Yet human "contributions can either mitigate or increase it."

Others believe that climate change is due to both natural and human causes. For instance, in the views of Philip, a catechist from Abakaliki,

TABLE 2. Summary of responses on the causes of climate change.

\begin{tabular}{|c|c|c|c|c|c|}
\hline No. & Cause & Catholics $(\%)$ & Anglican (\%) & Pentecostal (\%) & Total no. of respondents (\%) \\
\hline 1 & Human activities & $7(70 \%)$ & $4(40 \%)$ & $4(40 \%)$ & $15(50 \%)$ \\
\hline 2 & Nature & $1(10 \%)$ & $3(30 \%)$ & $1(10 \%)$ & $5(16.7 \%)$ \\
\hline 3 & Theological fatalism (divinely caused) & $1(10 \%)$ & $1(10 \%)$ & $1(10 \%)$ & $3(10 \%)$ \\
\hline 4 & Uncertainty & $1(10 \%)$ & - & - & $1(3.3 \%)$ \\
\hline 5 & Not knowledgeable & - & $2(20 \%)$ & $4(40 \%)$ & $6(20 \%)$ \\
\hline
\end{tabular}


TABLE 3. Summary of responses on climate change impacts in Nigeria.

\begin{tabular}{lccc}
\hline \hline No. & Impacts & Knowledgeable (\%) & Not knowledgeable (\%) \\
\hline 1 & $\begin{array}{l}\text { Flood and erosion, extreme heat, distorted rainfall patterns, heavy } \\
\text { sunshine, food shortage, cancer, infrastructural wreckages, } \\
\text { and death }\end{array}$ & $21(70 \%)$ & $9(30 \%)$ \\
& & & \\
\hline
\end{tabular}

The cause of climate change as you know, we have the natural and artificial causes. The artificial causes is when we human beings decide to cut down. . .trees along the forests, deforestation, that is, clearing the trees, and then thereby giving room for erosion and things like that.

The natural causes, according to him, are "volcanic and flooding." Yet a participant expressed uncertainty about the scientific basis of anthropogenic climate change. According to Collins, a Catholic seminarian from Kano, "if we don't know the future and cannot tell what tomorrow will look like" then there is no basis to conclude that human activities are the major causes of climate change. This finding aligns with the findings of Arbuckle et al. (2013) and Carr et al. (2012), which showed that a section of their participants expressed uncertainty about climate change. There were also two participants who expressed theologically fatalistic views about the cause of climate change. For instance, when asked what the cause of climate change is, Anthony, a Catholic from Calabar, says,

If I could say, in my own opinion, ... we can't attribute the (climate) change to a particular individual or a particular thing. . .it was meant to be so, because even if you go scripturally, they say, there is time for everything. Therefore, there is always cause for change.

This view was shared by Henry of Charismatic Renewal Ministry (CRM), Lokoja, who said that as a preacher, he looks at climate change, which, according to him, is "changes in the climatic conditions ... as an act of God." This response points to the influence of religious beliefs and values on climate change perceptions and reinforces the finding of Shehu and Molyneux-Hodgson (2014) among Muslim clerics in northeastern Nigeria. This view has been found to discourage proenvironmental action and engagement because people who hold such views tend to have a sense of helplessness in preventing a supposed divinely predestined event like climate change (Shehu and Molyneux-Hodgson 2014). This could largely explain why one of the participants (i.e., Henry) who expressed this view suggested "prayer" as the only role the church can play in addressing climate change in Nigeria. These present findings show how dicey and polarizing the issue of climate change is. Although the majority of scientists argue that climate change is basically anthropogenic, differing perceptions of the causes have been among the central issues in climate change debates (see Romm 2016).

As Table 2 shows, there are some religious denominational differences with respect to the perception of the causes of climate change. For instance, more Catholic participants expressed belief in human caused climate change than other participants thereby reinforcing Pepper and Leonard's (2016) finding that Catholics are more likely than those from evangelical and Pentecostal traditions to believe in anthropogenic climate change. This could be as a result of the general level of environmental/climate change awareness and consciousness in the Roman Catholic Church both in Nigeria and globally (see CBCN 2017b; Nwaigbo et al. 2011; Guardian 2015b; Pope Francis 2015; Williams 2015; U.S. Conference of Catholic Bishops 2015). Like Pepper and Powell's studies (Pepper and Powell 2013a,b), which found that the Pentecostal churches and their clergy typically occupy last or close to last position on a range of measures of environmental activity, the present study found that the Pentecostals had the highest number of participants who were found to be unknowledgeable about the actual causes of climate change. Also, of all the participants, only one Catholic expressed uncertainty about the actual cause of climate change. This suggests that religious/denominational affiliation influences the perceptions of climate change causation.

\section{2) IMPACT OF CLIMATE CHANGE}

Some participants in the current study expressed their views on the impacts of climate change, which included food shortages, flood and erosion, unpredictability of rainfall, cancer, extreme heat, infrastructural wreckages, and death. See Table 3 for summary of responses.

Interestingly, some of the participants who expressed views on the consequences of climate change were informed by personal experiences. Solomon, an Anglican Vicar, notes that climate change "violates our humanity, because when you dislocate that natural order, it affects our living, it affects our existence, it affects our lifespan, it affects everything about humanity.' Speaking specifically on the effect of unpredictability of rainfall on agricultural output, Matthew, an Anglican Vicar in Abakaliki, expresses that 
[t]he consequences (of climate change) abound around us. The shift of the usual seasons, like rainy seasons and the high harmattan...we have more of harmattan these days than the normal days, just like this year, we had to start the rainy season as far as the ending of March. People were still waiting to plant. . as late as May, unlike the former year...But this year...up till June, people were still planting. The side effect is disastrous, like this year, we would not have much of yield on rice, reason being that up till now we are still planting rice, while we are supposed to be harvesting a lot of it by now.

Lawrence, an Anglican Vicar in Lokoja, also talks about the impact of climate change on health. Climate change, according to him, "causes disease (such as) cancer and other internal diseases we experience now ... which our fore fathers did not experience." In the same light, Collins, a Catholic in Kano, relates climate change to the recent high rate of sunshine, which, according to him, affects the melanin, which in turn causes cancer. This high intensity of the sunshine, for Jonathan (Winners, Calabar), reduces the lifespan of people. Clement, a Catholic priest from Abakaliki, buttresses this view with an example from Abakaliki, Ebonyi State, Nigeria. According to him, "I will give you example with Abakaliki here, the type of sun we experience nowadays is not ... the way it used to be, I mean the sun is becoming too high which is part of that climatic change." Anthony, a seminarian, on his own part relates climate change consequences to asthma, saying that the climate change induced extreme cold weather, which usually affects asthmatic patients.

Flooding was heavily cited by the participants as the most common consequences of climate change. In most cases, these participants made references to their experiences of incidence of flood especially that of the year 2012 in Nigeria. Ushie, a catechist from Calabar, for instance, narrates his experience thus: "there was a year, probably that was 2008 , we had a rainfall, everywhere was flooded, and some houses were affected (and) people were like wondering where to stay." This according to him causes trauma. Narrating his own experience, David, a Catholic from Lokoja, says,

sometimes there is rainy season, and this rainy season. . .carry some, even though it carries blessings, ... disasters like we had in 2012. We had a terrible flood disaster in Kogi state. Mind you, I am a member of Nigerian Red Cross Society, and we also participated effectively in that disaster that happened in 2012.

Frank of Christ Embassy, Kano, also talks about the heavy wind storms that usually come with the heavy rainfall in Kano State. These, according to him, leave many buildings in total wreck. However, some of the participants were unable to identify any climate change impact. The impacts listed by these participants have been confirmed in some circumstances to be attributable to climate change (see Bharath and Turner 2009; Chinowsky et al. 2015; Connolly-Boutin and Smit 2016; Masselink and Russell 2013; U.K. Department for Environment, Food and Rural Affairs 2012; Miranda et al. 2011). This shows that some of the participants are familiar with the impacts of climate change probably because of the fact that some of them had experienced some of these impacts. This supports the findings of Lujala et al. (2015), which state that an important factor explaining people's perception of climate change and its possible consequences is their experience of damage caused by climate change-related events such as flooding or landslide. Of these impacts, flood, extreme heat, and distorted rainfall patterns are the most common experiences the participants narrated to have had. Studies have also shown that these three impacts are at the vanguard of all climate change impacts confronting Africa (Serdeczny et al. 2016; Adhikari et al. 2015). These impacts affect agriculture and livelihood in Africa and Nigeria in particular (Apata 2012; Pereira 2017) just like the Anglican participant who reported how his rice production in Abakaliki has been affected by the distorted rainfall patterns and unpredictability. Beyond these, this finding goes to prove in addition to documented evidences, that climate change impacts are occurring in Nigeria, as most of the participants attested to its reality based on personal experiences and observations.

\section{b. Perception of church's role}

Participants also expressed their opinions on the role of the church in addressing climate change. Awareness creation, charity for disaster victims, and prayer are the major roles the participants suggested for the church in her response to the phenomenon of climate change. However, there are religious denominational differences with respect to the perceptions of churches' role in addressing climate change. For instance, more Catholic participants, unlike other participants, emphasized the need for churches to create climate change awareness. They also reported of specific environmentally friendly actions (e.g., not using chemicals to kill grasses) they have already engaged in because of the church's (i.e., Catholic Church) efforts to promote care for the environment through notable documents such as Laudato Si. This highlights the importance of religious figures in fostering global climate change concern. For instance, Catholic participants cite the teachings of Pope Francis to explain why they recognize climate change as a significant issue. Perhaps the reverse would have been the case if the Pope had not encouraged or called for climate 
TABLE 4. Summary of responses on the role of the church.

\begin{tabular}{|c|c|c|c|c|c|}
\hline No. & Role & Catholics (\%) & Anglican (\%) & Pentecostals $(\%)$ & Total $(\%)$ \\
\hline 1 & Climate change awareness creation & $9(90 \%)$ & $5(50 \%)$ & $4(40 \%)$ & $18(60 \%)$ \\
\hline $1 \mathrm{a}$ & Focus on soul winning/salvation & - & - & $1(10 \%)$ & $1(3.3 \%)$ \\
\hline $1 b$ & End-time awareness creation & $1(10 \%)$ & - & $1(10 \%)$ & $2(6.6 \%)$ \\
\hline 2 & Charity for disaster victims & $5(50 \%)$ & $3(30 \%)$ & $3(30 \%)$ & $11(36.7 \%)$ \\
\hline 3 & Prayer & - & $1(10 \%)$ & $3(30 \%)$ & $4(13.3 \%)$ \\
\hline
\end{tabular}

action through Laudato $\mathrm{Si}$. This, to some extent, reinforces the findings by Carr et al. (2012) and Wilkinson (2012) that the most effective way to make Evangelicals see climate change as a significant issue would be through discussions initiated by known pastors.

In contrast, Pentecostals seem not to have recognized climate change as an important issue, perhaps because there is yet to be a definite positive statement on climate change from their known and respected leaders. For instance, one participant reported that the church should focus on salvation rather than climate change awareness creation and two others stated that the "awareness" the church should create is to let people know that climate change is a sign that the end is near. Two of these three participants are Pentecostals, suggesting their religious affiliation could explain their perceptions. These findings are interesting because they suggest that even in places where the impacts of climate change are directly visible, theology affects perceptions. See Table 4 below for summary of responses. These roles are discussed below.

\section{1) AwAreness CREATION}

Of these roles, awareness creation dominated participant's opinion, although expressed in different words such as enlightenment, education, sensitization, preaching, teaching and so on. For instance, responding to the question, Do you think the church has any role to play in addressing climate change, what are the roles you think the church can play? Angela of CRM, Lokoja, says,

Possibly! The church can counsel people on the way we handle our environment. Just like I said earlier, this climate change could be caused by our human activities. So, maybe the church could educate the members on what they should do and what they should not do. Just to play our own role, to tame the effect.

Responding to the same question, Matthew of Anglican Communion, Abakaliki, responds with more assurance:

Why not! We have spiritual and social roles. I strongly believe that there are parts the church must play. What of the deforestation we have faced? Tearing down every bush, how many have we planted? We pull down trees without having reasons. People get up to tear down the forest, level them for industrial developments, without actually finding a place to replace them. What of some of the animals, all these creatures contribute to man's wellbeing. Some of the chemicals we have developed to handle our grasses, have we actually sat down to ask ourselves the consequences? ...We cannot run away from them. These are realities around. The church can actually go a long way in sensitizing their members on what, (or) how to actually keep some of these trees around us. These trees can actually help us check the level of carbon emitted in the air. . Today we live in the street you barely see one tree standing, even when the government plants on the main road, we are too careless about them. We even cut them down to make fire woods. So we are not conscious of our environment. We are not conscious of preserving the nature that God gave us. So, the church should actually sensitize their members on some of these things.

On his own part, Godwin of Anglican Communion, Lokoja, submits that

Apart from other social gatherings, I think church has the highest number of people that congregate, day in, day out, virtually every day... Some of these (climate change discourses). . .could form part of a kind of a study. There is nothing that is happening that is not linked to the scripture. . The pastor himself, even if not well informed in that area, (could) invite people that are informed to talk to the members. Even in our own corner, we can start those things. . .It doesn't have to be federal government; we can join hands together and do that. (There can be) awareness (on) the side of the youths, who from their own youthful exuberant, also contribute to some of these problems...A lot of things can (be) checkmated...

Also acknowledging the potency of the church platform in the creation of climate change awareness, Jonathan of Winners Chapel, Calabar, says,

The church, actually, is one of the biggest coordinating society [sic]. That is how I see it. So they have a very large role to play in the entire society. In the society, they have power to even influence the whole society. Yes! . . because whatever the church says, the people believe... and believe who is saying it...So if a minister can decide to communicate with people and tell them look, to mitigate this thing, to reduce this disease, just take care of so, so, so 
like waste, avoid indiscriminate dumping of refuse, this is the cause, this is how it results. It can affect your health, why won't they change? Because they believe that whatever comes from a man of God is true.

Similarly, Clement, a Catholic priest in Abakaliki, expresses his views on the influential nature of the church with respect to climate change awareness. However, he takes the task directly to the doorsteps of church leaders. According to him,

Well, yes, the church can play some roles like that because you know, a lot of people come to church and people tend to listen more to religious leaders than political leaders, and if the church or the church leaders or religious leaders whom people listen to more, and. . accept what they say more, if they should enlighten people based on this climatic change, and how to, at least. . not how to prevent it now, but at least how to get ready for it, or possibly prevent it, for example, something like flood, you can prevent it. But if it is something like too much heat, sun, all those things, you can't prevent it but at least, how to manage it. The church leaders can decide one or two times enlighten their members on how to go about all those things, how to avoid flood, how to run away from it. People usually say how can I run away from my home, leave my ancestral home and go where? No! But a church leader can talk to them, appease their consciences, tell them the dangers there, and coming from a religious leader, they can accept it, they can say ok, if so, so and so person said so, then it means we are still safe where ever we are going. So, they can enlighten people.

Also in the view of Solomon, an Anglican vicar in Abakaliki, the church has "a lot of" roles to play in addressing climate change. According to him,

They should educate their members that they are the ones destroying the gift of God to them...And they are responsible, since we are responsible human beings, we are responsible people, responsible humanity, we have to take responsibility and teach them. . that we can destroy our lives by destroying the ecosystem...The church should teach its members that we are mere caretakers of this world, of this earth, that God is the owner, and then we should do stewardship economy and not materialistic economy.

Solomon also goes further to suggest that beyond education, the church could also engage in some activities such as tree planting.

This finding corresponds with Carr's (2010) finding among conservative Christians who also emphasized the need for Christians or churches to respond to climate change through the creation of awareness in the form of "evangelism." However, unlike Carr's study where the participants suggested that churches can create climate change awareness only on the condition that it does not replace the real focus of churches, the participants in the present study who suggested awareness creation on climate change were unequivocal and with no clause. This, to a great extent, is a show of willingness to address climate change in Nigeria.

Some participants in the present study specifically talked about how influential churches and religious leaders are both on religious and political matters-a position that had already been affirmed by Djupe and Gilbert (2009) in their book titled The Political Influence of Churches. This influence appears to be very pronounced in Nigeria, as Clement, a Catholic Priest in Abakaliki, notes "a lot of people come to church and people tend to listen more to religious leaders than political leaders." For these participants, this particular feature makes the Church a potent platform to create climate change awareness. Although the likes of Taylor (2009) have questioned the capacity of religious groups to develop effective green theologies since there is little evidence of significant faith-based climate action in the United States despite 20 years of efforts, the situation in Nigeria may be different from that of the United States as religious leaders appear to have greater social status and influence in Nigeria.

Furthermore, while responding to the same question, on what the church can do to address climate change, some participants make references to what their churches have done already, suggesting that some churches are already addressing the phenomenon. For instance, Dominic, a catechist in Lokoja, says that

[t]he Catholic Church, in his wisdom, has been preaching, and has been talking about the necessity of maintaining our climate, trying to save the ozone layer. If you check, almost every Catholic mission house, you would have noticed that all the grasses here are green, we don't spread chemicals to kill our grasses, we only cut them low, so by that you should know that the Catholic church has a way of telling its members and teaching them on how to keep their environment, so that they can also save the environment from this situation.

Similarly, Collins, a Catholic in Kano, observes thus:

Of course, of course, the church has been doing a lot. There is a document we call. . Laudato $\mathrm{Si}$-am just trying to translate it...in French (which is the language) I studied it. The church is calling its members and the world to join hands to save humanity, because the church also has scientists. It is not just the secular world that has scientists that can prove all those things. But the church also has scientists that have worked on it and they have seen the effect. So, it is a joint work to save humanity. It is not left for the scientists to determine or to save. And in that Laudato Si, like what you are seeing here, normally, they shouldn't cut these grasses, they should just. . leave 
it like that because it also gives life to certain things. . .And many industrial activities, the call on people to checkmate all these things. We should explore other means. . .to exploit our natural resources. . if not, everything will go to ozone layer and everything now will begin to have direct contact. . from the sun...

However, like Carr's (2010) study in which 10 participants were found to have said that in their opinions, churches have other foci that are more important than climate change, the present study had a participant (Michael of Christ Embassy, Kano) who feels that climate change is not within the focus of the church. For Michael,

The church is consecrated for something which is reconciling men to God, which is the primary reason of the church. The church...you see, is not a building but the people that comes in there to worship. And you know in every organization there is a focus, and when you derail from your focus, you miss your point and you don't get your objectives. So...the major focus is reconciling and making people to know there is a life after here. . So, this is the major focus. So I don't think that. . the church is saddled with such responsibility to educate their members on climate change, because it is not the major focus.

Hence, the church should not be expected or held responsible for doing nothing about climate change. This of course does not encourage proenvironmental concern especially at the church level. Little wonder that Michael and his church were reported to have done nothing both personally and organizationally to address climate change. Some other participants accepted that the church has a role to play [Jumoke, Redeemed Christian Church of God (RCCG), Ogun; Anthony, Catholic, Calabar] in response to climate change but differed on the content of the awareness creation. For these participants, the church should rather let members know that climate change alongside its impacts is a sign that the end of the world is at hand. This, for them, would be necessary to make members prepare for the "coming of Jesus." This again, points to the influence of religious beliefs on participants' perception and action on climate change.

\section{2) CHARITY FOR DISASTER VICTIMS}

Charity for disaster victims is the second role or action participants suggested for the church in her response to climate change. According to Anthony, a Catholic in Calabar,

It is the churches' responsibility to help every community who experience such. Yea, we said that if you can, before you say love God, you need to love... your neighbour first. So it is church responsibility to help others who are experiencing or who have problem in their own locality, at least, with such help, they will overcome the problems or the feeling of rejection. So, it is the church role and responsibility to help them.

Corroborating this, Humphrey, a Catholic in Kano, adds,

You know. . it is always devastating whenever people are affected. As a human being, you feel maybe, that empathy, that if you are the one, or even though you are not the one, it is not because you are more righteous than the other person, just that it has not come to your place. So, you need to sympathize with people that have witnessed these things...

Michael of Christ Embassy, Kano, also expresses his opinion on the role of the church toward disaster victims. While he agrees that the church should extend a helping hand to these victims, he, however, seems to be limiting the church's charity to cases that directly affect the church or to only members of the church (i.e., in this context, his church, Christ Embassy):

Yea, church can come in there because if I have a member that has been displaced, I don't expect him to be in church, when he doesn't have a place he lives. So this is what the church is all about. The church now has to come in, in rendering assistance in one way, or to give that person a better habitation where that person can, because psychologically, if a person does not have a house, he might not be able to participate in most things that we do. So indirectly or directly, it affects the church.

This is in line with the social justice aspects of climate change, which also align with the Christian duty to help the poor and needy (Prelli and Winters 2009; Sachdeva 2016). This is rooted in the belief that climate change is an environmental problem that disproportionately affects the poor and those living in disaster-prone areas or zones across the world (Adger 2006; Brown 2001; Thomas and Twyman 2005). To this end, apart from the calls to address climate change, the call to also assist victims of climate change induced disasters has also been made by some religious figures and leaders (see Evangelical Climate Initiative 2006; Pope Francis 2015). This is the view expressed by participants in this present study. However, while some participants spoke of the actions the church should take toward disaster victims, some participants spoke of charitable activities their churches embarked on during the popular year 2012 flood that ravaged the entire country. According to David, a Catholic in Lokoja, "when we had flood in 2012, the church came in to assist some persons. They even asked people to park and...not to build along water areas. . even this our church. . water was almost carrying parish priest's house." Similarly, Henry of CRM, Lokoja, narrates 
how his church assisted victims of the 2012 flood disaster in Kogi State:

When it happened in 2012, we had some of our members who are in those prone areas. So we had to assist, trying to provide alternative place for accommodation...And then those who had challenges, we tried to see how we can meet their needs. So that was the role we played. Sometimes, in situations like that, people like that are helpless and there is the need for us to intervene.

Interestingly, these participants are from Lokoja, Kogi State (i.e., David, a Catholic, and Henry, CRM, Lokoja), which was reportedly among the worst hit states during the flood (Bashir 2014; Ibekwe 2012). The report of the Environmental Right Action/Friend of the Earth Nigeria (ERA/FoEN) observes that,

In Kogi State, ...more than 500 thousand people were displaced. Nine out of the 21 local government areas were hit, with the worst affected being Ibaji that is completely submerged. The community occupies an area of 1,377 square kilometres and has a population of over 150 thousands. Other affected areas in the state are Lokoja, Bassa, Idah, Omala, Ajaokuta, Igalamela/Oddu, Ofu and Ankpa.

This highlights the place of direct personal experience in climate change mitigation and adaptation in the sense that people who had experienced climate induced disasters such as flood are more likely to take actions than those who have not. A participant (Steven, Anglican, Kano) also talked about the charitable work of the Synagogue Church of All Nations (SCOAN) to Ecuador following the colossal earthquake that happened on 16 April 2016. The SCOAN reportedly sent relief materials to the victims of this disaster.

\section{3) PRAyer}

A few participants suggested prayer as either the only role or part of the roles the church can play in addressing the phenomenon of climate change. Henry, of CRM, Lokoja, for instance, sees climate change as a divinely caused phenomenon. Hence, when asked what he thinks should constitute the role of the church in addressing climate change, he replies,

Yes, the extent that I know about, is we try to ask people to pray. Be very prayerful! because we look at the effects from the climate change, and we look at it as a disaster, and we believe that God has a way of handling things. So pray, so that we are not exposed to some of these disaster things.

On his part, Lawrence, an Anglican vicar in Lokoja, suggests that prayer, albeit not the only thing the church should do, is the major role the church can play in addressing climate change. For him "above all [i.e. the need to preach about climate change], the church should also pray as Christians believe that there is nothing that prayer cannot handle." As interesting as it seems, it should be noted that this belief is common among Nigerians. Onah and Ugwu (2008) have through their article recommended "prayer" as the panacea to all the problems or challenges facing Nigeria. Ibikunle Amosun, the governor of Ogun State, was also reported to have recommended prayer as the solution to Nigeria's problems at the formal opening of the 2017 Standing Committee meeting of the Church of Nigeria (Anglican Communion) held in Abeokuta, Ogun State (see Osijonwo 2017). Specifically, Ugwu and Chukwuma (2012) presented prayer as capable of solving Nigeria's national security challenges. This belief to a great extent explains why there are numerous prayer houses or designated prayer mountains in Nigeria (see Okonoboh 2016). Hence, it is not surprising that some participants expressed belief in prayer as the solution to the phenomenon of climate change in Nigeria. Yet, this belief is informed by a stronger belief in the sovereignty and omnipotence of God who is believed to possess the power over all things. However, while this belief is important, especially among Christians, it seems not to be capable of achieving much without corresponding work especially with respect to climate change mitigation and adaptation in Nigeria. Climate change mitigation and adaptation in Nigeria needs concerted efforts in the forms of practical and efficient proenvironmental actions and adaptation strategies.

\section{c. Climate change action}

Participants generally reported on their climate change actions both on personal and church-levels. While some reported to have occasionally planted and nursed trees, flowers, or grasses, others reported to have engaged in some sort of awareness creation among their congregations or groups. Yet, there are others who reported to have engaged in some activities like farming, environmental sanitation and so on. However, a number of the participants reported to have done nothing to address climate change either on personal or church levels (see Table 5 for details). These climate change actions/inactions are, in considerations of the two basic types of engagement, categorized into three: organizational action (i.e., action performed at the church level), personal action (i.e., action performed at the individual level), and inaction (i.e., inaction at both individual and church levels).

\section{1) Organizational/CHURCH LEVEL}

Some participants in the present study reported climate change action at the organizational/church level. 
TABLE 5. Summary of responses on climate change action.

\begin{tabular}{llcccr}
\hline \hline No. & Type of engagement & Catholics (\%) & Anglicans (\%) & Pentecostals (\%) & Total (\%) \\
\hline 1 & Organizational Action & $7(70 \%)$ & $3(30 \%)$ & $1(10 \%)$ & $11(36.7 \%)$ \\
2 & Personal Action & $4(40 \%)$ & $4(40 \%)$ & $5(50 \%)$ & $13(43.3 \%)$ \\
3 & Inaction & $1(10 \%)$ & $3(30 \%)$ & $4(40 \%)$ & $8(26.7 \%)$ \\
\hline
\end{tabular}

For instance, when asked if his church has done anything to address climate change, Philip, a catechist in Abakaliki, replies,

In my parish, I think you have been there, if you enter St. Patrick, you will see that there is a kind of change, because we planted trees at some areas to preserve nature and then protect the church from climate thing, like when there is a heavy wind, you discover that the trees try to wage the wind from destroying some of the buildings. And other people are also copying what we have done.

Also, reporting on the action his church has taken in addressing climate change, Collins, a Catholic in Kano, says,

Yea, the church is doing so much. Sanitation is very important, trying to clear...especially if you see... we try to clear the gutters. . Each diocese, even at the parish level, where like today, the youths is (are) doing sanitation...to protect our environment and...to avoid natural disaster or blockage in the gutter, and outbreak of disease. So... that is what we are doing and virtually every Saturday we mobilize the youth at the parish level to do that.

Responding to the same question on his church's climate change action, Matthew, an Anglican vicar in Abakaliki, says,

I think for the month of April/May, we had "healing the land" and we talked of caring for the environment. The theme for the year is healing the land. But the topic we were treating was caring for our environment...It was a period to actually look and see how much man has destroyed the natural environment, that has turned back to hurt him, and what we can actually do to boost the condition.

Daniel of Winners Chapel, Calabar, also reports that "if you look around our environment, like opposite the airport there, people are not encouraged to cut down trees" and there are also plans to plant trees within the church premises. Similarly, Clement, a Catholic priest in Abakaliki, says the following about his church's climate change action:

Well, for enlightening the people, I think telling them to avoid blocking the water channels and all those things. Most at times we don't talk about industrialization here because most of the things that bring about climate change, at least, $80 \%$ is industrialization, and it is. . .out of option here, almost out of option here. But there are other things like burning of unnecessary things, tires and all those things. . .contribute and people have been advised to avoid all those things.

\section{2) Personal action}

There are some participants who reported to have engaged in some proenvironmental behaviors or climate change actions only at personal levels. Henry of CRM, Lokoja, for instance, reports to have personally planted trees. But according to him, "the trees we plant, in my own compound are for purpose of consumptions, because some of those things are edible. We planted Mango; some of them died and couldn't survive. My idea was not to preserve the environment, but for me to have fruits. And I also... have a plan to plant some trees as shade. There is a way I am designing my compound." Then, when asked if his church has engaged in any climate change-related action, Henry replies with reference to the year 2012 flood, "our own environment, the church environment were not affected by flood. You know we are upland. Those who are upland were not affected."

Similarly, Moses of Assemblies of God, Abakaliki, reports to have personally engaged in some actions like controlling erosion by putting up a ridge across a sloped area, "so that the speed of water...will be slow." However, when asked if his church has done anything to address climate change, Moses quickly replies "No." This was corroborated by Peter, the senior pastor of the church, who says, while responding to the question on church climate change action, that

[1]ike I said before, in this part of the world, we don't actually...we don't have much involvement. For instance, if there is much erosion and all these things, we would have said ok, but here is a stable land.

There were others who reported inaction toward climate change both at the organizational/church and personal levels (i.e., complete climate change inaction).

It is notable that most of these actions were sparingly carried out (except for environmental sanitations) with no direct intention to address climate change. They were rather initially meant for beautification or aesthetic and consumption purposes (e.g., the trees, flowers, grasses). 
The participants' inadequate knowledge of climate change, as have been found in this study, could largely explain the occasional nature of these climate change-related actions as well as the lack of intentionality in the performance of the actions. Yet, some of these actions are relevant for climate change mitigation and adaptation. For instance, tree planting has been shown to be relevant for both mitigation and adaptation in the sense that trees absorb carbon dioxide $\left(\mathrm{CO}_{2}\right)$ (mitigation) and provide shade and help control erosion (adaptation) (see Gill et al. 2007; Hamin and Gurran 2009). Although flower and grass planting may not have had heavy documented direct climate change relevance, they could help control erosion (see Beyers 2004; Gyssels and Poesen 2003; Zuazo and Pleguezuelo 2009), which could be a good local climate change adaptation strategy.

Those who reported incomplete climate change action as well as those who reported complete inaction advanced some reasons for their actions and inactions. Some of them reported not to have had direct experience of climate change impacts like Henry of CRM, Lokoja, who said his church has not been affected by flood because it is situated on a hill. Peter of Assemblies of God Church, Abakaliki, who said they are not so much involved in the issues around climate change as there is no climate change impact around their area, is another case in point. This suggests that personal experience influences climate change action. For instance, if churches are in areas where erosion or flooding affects the church grounds or the community, they are more likely to engage in environmental actions than upland churches. This, unlike Whitmarsh's (2008) study, shows that flood victims or people who had direct experience of climate change impacts are more likely to respond to climate change than people who have not had such experiences. This is in tandem with the findings of Spence et al.'s (2011) study that shows that those who report experience of flooding express more concern and willingness to mitigate climate change.

The study also found that generally, there were more climate change actions on personal levels than on organizational/church levels (see Table 5). This shows that churches are yet to appreciate the reality of this phenomenon of climate change in Nigeria and the need to address it. It also shows that individual participants, who reported to have engaged in one climate change-related action or the other, are also yet to realize the need to address it at the organizational/church levels as church leaders in the respective denominations. Even the reported individual climate change-related actions were unfortunately occasional and never intended to address climate change.
On the organizational/church levels, the Catholic Church was found to have taken more climate changerelated actions. This is closely followed by the Anglican Church and then Pentecostal churches, which are behind with a great margin. Also, among Catholic churches, it was found that there were more climate change actions on the organizational/church levels, than on the personal levels. In contrast, climate change actions were more on personal levels than on organizational/church levels within Pentecostal churches. This reinforces the report of Williams (2015) that ranked the Catholic Church first among the eight Christian denominations with the most liberal views on the environment. Beyond this, the Roman Catholic Church has a long history of environmental consciousness and activism. Beginning with Saint Francis of Assisi, through the eras of Popes Paul VI and John Paul II, to the current era of Pope Francis, this environmental consciousness has been waxing stronger and far-reaching. The call to care for God's creation that is encapsulated in Laudato Si has been bringing Catholics across the world to pledge to care for the creation and the world's poor. At the moment, many American Catholics have taken the pledge (U.S. Conference of Catholic Bishops 2015).

In Nigeria, there have been indications of this environmental or ecological consciousness. The series of Catholic-sponsored climate change-related conferences and publications (see: CBCN 2017b; Nwaigbo et al. 2011; Guardian 2015b) are cases in point. These perhaps explain why Roman Catholic churches were found to have taken more climate change-related action at the church levels than Anglican and Pentecostal churches in the study. Yet, it should be noted that most of the actions were occasional and never intended to address climate change thereby pointing to the fact that generally church leaders have not yet appreciated the dangers of climate change and the need to address it in the country.

\section{d. Implications of the findings for churches/church leaders}

Basic findings of this study were that climate change knowledge, albeit with some religious denominational differences, is narrow while action is generally poor among church leaders in this study. Even the climate change-related actions that were reported were merely occasional and unintended for climate change. Of course, as nonprofessionals or experts in climate change science, as many of the participants also acknowledged, one could not have expected otherwise. Yet, considering the future ecological threats or disasters that await climate change indifference and/or inaction, everyone needs to be abreast 
with the fundamentals as well as actively responsive to the phenomenon of climate change. In fact, it has been projected that climate change will negatively impact the world more than the way the Internet is currently impacting the world (Romm 2016).

This highlights the imperativeness of climate change mitigation and adaptation in Nigeria. Hence, church leaders need, in complete appreciation of the dangers of climate change, to rise to the challenge of the time. The church leaders need to be properly equipped with climate change knowledge to be able to apply it in their respective local churches and groups. One major step to achieve this is to incorporate or integrate climate change education into the curricula of the theological/seminary schools for all Christian denominations in Nigeria. The implementation of this suggestion, of course, falls on the tables of the overall leadership of Christian denominations such as $\mathrm{CBCN}$, the Anglican Primate and his bishops, the general overseers of individual Pentecostal churches, and other stakeholders such as CAN, PFN, and so on. One is aware that some churches might already have a place for studies in forms of eco-theology, ecohermeneutics, etc. in their theological schools, but those seem to be inadequate. This is because most of these studies usually focus on only the humanistic or theological approach to the issue of ecological crisis/climate change. The science of climate change that focuses on the causes, impacts and relevant measures of mitigation and adaptation could be incorporated into the curricula. Then, for the lay leaders, climate change conferences, seminars, or workshops on the issue of ecological crisis/climate change could be occasionally organized on denominational levels to further inculcate climate change knowledge through cross-fertilization of ideas that are characteristics of academic conferences/workshops. These and more will prepare these leaders to educate their congregations or groups on the phenomenon of climate change in their various churches.

Afterward, these leaders could go beyond mere acquisition of climate change knowledge and education of their members, to engaging in active proenvironmental behaviors. This is necessary as Holland and Carter (2005) have found out that ministers' or church leaders' environmental or climate change knowledge alone does not increase the likelihood of a congregation being environmentally active, but, when ministers put their words into practice, congregations are more likely to be active.

\section{e. Implications of findings for policy and future research}

Some of the findings of the study have important implications for both government and nongovernmental organizations in Nigeria. First, climate change was perceived and interpreted in various ways that are not consistent with the scientific knowledge or conceptualization of climate change. For instance, some participants viewed climate change as change caused by human activities, natural forces, God, unidentifiable cause, etc. This suggests that climate change knowledge is poor among the participants. Apart from the role of some deeply held religious values that affected participants' climate change perceptions, this could be largely pointing to lack of accessible sources of climate change information, which to a great extent implicates the government and the nongovernmental climate change/environmental organizations in the country. Admittedly, organizations such as Building Nigeria's Response to Climate Change (BNRCC) and the Nigerian Environmental Study/Action Team (NEST) in collaboration with the Federal Ministry of Environment Special Climate Change Unit and the Canadian International Development Agency have executed some campaign programs and research projects on climate change mitigation and adaption in Nigeria. Some of these projects/reports include Climate Change Scenarios for Nigeria: Understanding Biophysical Impacts; National Adaptation Strategy and Plan of Action on Climate Change for Nigeria (NASPA-CCN); Gender and Climate Change Adaptation: Tools for Community-Level Action in Nigeria; Learning from Experience-Community Based Adaptation to Climate Change in Nigeria, etc. Also, there have been some efforts by the African Climate Change Adaptation Initiative [ACCAI, University of Nigeria (UNN)] through the organization of seminars and workshops aimed at creating climate change awareness especially in the University of Nigeria. The recently concluded workshop on the theme "Securitization of Climate Change and its Impact on Risk Governance in Nigeria" held on 16 January 2018 is a case in point. This workshop was organized by the Department of Geography, University of Nigeria, Nsukka, in collaboration with the University of Stavanger, Norway.

Despite these efforts, however, climate change knowledge is evidently narrow especially among the participants in this study. It is either that these efforts are inadequate or that church leaders are often neglected in these climate change awareness campaign programs and projects in the country. This raises the need for improvement on climate change awareness campaigns in the country. Both the government (at the local, state, and national levels), and nongovernmental organizations need to, in recognition of the important place of church leaders, capture church leaders in their climate change awareness activities. Organizing or sponsoring special workshops or seminars for them would not be out of place. Nigerians need to be 
aware and knowledgeable about climate change and if that should be achieved, then church leaders are indispensable. Beyond mere awareness or knowledge, Nigerians need to believe and be committed to proenvironmental behaviors, climate change mitigation, and adaptation and if this should be achieved, church leaders are again indispensable. This is due to the fact that church leaders wield a lot of influence in the country. This of course was confirmed by some of the participants in the study. In fact, about 85 million persons congregate under these church leaders on weekly basis in Nigeria (see Pew Research Center 2011). Therefore, engaging these leaders on the issue of climate change would have a desired impression on their congregations. Accordingly, it has been shown that congregations that have environmentally engaged ministers or leaders who emphasize the consequences of environmental degradation, might consist of more environmentally concerned members. (Truelove and Joireman 2009; Veldman et al. 2014).

Second, the study has shown, in addition to the documented evidence, that climate change is real and being felt in Nigeria. Virtually all the participants attested to the reality and impacts of climate change based on their personal experiences and observations. This goes to show that urban dwellers also feel the impacts of climate change in the country. This is important because majority of the sponsored research projects such as that conducted by NEST and BNRCC have always focused on highlighting the vulnerability and impacts of climate change in rural communities in Nigeria (see NEST and Woodley 2012). A participant, for instance, narrated how the distorted rainfall patterns have affected their agricultural activities such as the rice production in Abakaliki, the capital city of Ebonyi State. Future researchers need to therefore examine climate change vulnerabilities and impacts in urban areas or cities in Nigeria. Yet, it is a fact that rural dwellers especially women and children are more vulnerable and susceptible to climate change impacts (NEST and Woodley 2012). However, this reality of climate change impacts in the cities across the country should have implications on climate change governance in the country. While some of the already existing climate change policies and projects such as NASPA-CCN are running, the government, through the Department of Climate Change at the state Ministries of Environment, should enact more policies to effectively address climate impacts at state levels. But, beyond climate change policies, the governments at all levels should focus more on building mitigation and adaptation capabilities in Nigeria. Climate change vulnerability is occasioned by multifaceted factors such as ecological, sociocultural, and political factors. Ecologically, many people live in disaster-prone areas such as those in drought- and flood-prone zones in northern and southern Nigeria, respectively. Socioculturally, some communities have rigid cultural land-use practices that limit the rights of indigenous people especially women to own and cultivate lands. Politically, there is lack of strong political will, weak institutions, high poverty rate, high unemployment rate, and poor infrastructural development in the country. Therefore, to effectively build climate change mitigation and adaptation capacities, these developmental issues (i.e., ecological, sociocultural, and political issues) need to be addressed in the country.

Third, the study found that religious affiliation/denomination and personal experiences influenced perceptions of climate change causation and climate change action among the participants. These findings add important perspectives to the body of knowledge on the factors influencing climate change perceptions and actions. The findings also highlight what seems to be a recurrent pattern in the literature, which is that Catholics are more likely to believe that climate change is real and caused by human activities and to take actions to address the phenomenon than other denominations, especially the Pentecostals (see Pepper and Leonard 2016; Pepper and Powell 2013a,b). While theological differences could partly account for this seemingly consistent pattern with respect to climate change perceptions, the roles of Catholic leaders also seem to be a significant factor. The roles of successive Popes in creating environmental/climate change consciousness within and outside the Catholic Church are well documented (see Pope Francis 2015). Interestingly, some of the Catholic participants in the present study cited Laudato Si to explain why they have recognized climate change as a significant issue that needs to be addressed. This suggests that for other denominations, especially the Pentecostals, to recognize climate change as an important issue, there need to be official statements from known and respected leaders of their churches. Hence, government agencies seeking to enlist faith leaders in promoting climate action in Nigeria need to reach out to Pentecostal and Anglican leaders for help in spreading the word among their churches. Also future research should investigate different approaches to discussing climate change with other denominations especially the Pentecostals, in order to achieve a more meaningful faith-based climate action in Nigeria.

This study has some limitations that give directions for future studies. First, even though participants were drawn from five geopolitical zones of Nigeria, the sample size is small. This is, however, characteristic of 
qualitative studies and as such generalization of their findings should be done with caution. A larger sample size need to be undertaken in future studies on climate change attitudes among church leaders in Nigeria. Second, although this study found that some participants had their climate change perceptions influenced by some religious beliefs and values; it could not dedicate adequate space and time to thoroughly examine the implications of these influences. These influences, however, suggest, unlike the position of Shehu and Molyneux-Hodgson (2014), that religion could be a strong factor that could determine peoples' climate change perceptions and actions in Nigeria. Therefore, future research is need to explore the influence of religious beliefs on climate change perceptions and actions in Nigeria by specifically investigating the connection between strongly held religious views and climate change realities and the implications of such connections, if any, on climate change mitigation and adaptation among adherents in the country.

\section{Conclusions}

Climate change has become one of the daunting challenges facing the global community in this twenty-first century. Already, several societies, especially developing countries such as Nigeria, are bearing the brunt of its impacts - a reality that makes mitigation and adaptation vitally important. This study has explored the role of church leaders, a socially and politically influential set of people, in addressing climate change in Nigeria. Apart from the anticipated improved policy-driven mitigation and adaptation, the study has highlighted the need to creatively engage church leaders in order to achieve an effective climate change mitigation and adaptation in Nigeria. The need for creativity in such engagement lies in the fact that church leaders evidently perceive climate change variously, and these differences often seem to be informed or influenced by their religious affiliations and convictions. Communicating the reality of climate change to them, therefore, requires dialogue geared toward securing their support and partnership in the fight against climate change especially in Nigeria. Fortunately, virtually all the participants in this study expressed serious concern and willingness to address climate change. Hence, the government and other stakeholders should leverage this positive disposition by providing the necessary support and platforms for effective climate change education for these leaders. On the other hand, church leaders should actively join the global campaign to save Earth by creating or building climate change awareness and commitment in their local churches.
TABLE A1. Interview questions.

\begin{tabular}{|c|c|}
\hline No. & Question \\
\hline 1 & $\begin{array}{l}\text { What is your age, highest educational qualification, } \\
\text { weekly church attendance frequency, position in the } \\
\text { church, the name and location of your church? }\end{array}$ \\
\hline 2 & What do you know of climate change? \\
\hline 3 & $\begin{array}{l}\text { What do you think are the causes and } \\
\text { effects/consequences of climate change? }\end{array}$ \\
\hline 4 & $\begin{array}{l}\text { Do you have doubts on issues of climate change? What } \\
\text { issues come to mind as you hear or ponder on climate } \\
\text { change? }\end{array}$ \\
\hline 5 & $\begin{array}{l}\text { Do you think the Church has any responsibility to } \\
\text { address climate change? What roles do you think the } \\
\text { Church has in addressing climate change in Nigeria? }\end{array}$ \\
\hline 6 & $\begin{array}{l}\text { Have you or do you engage in any action to protect or } \\
\text { preserve the environment? What are the actions you } \\
\text { have taken to address climate change? }\end{array}$ \\
\hline
\end{tabular}

\section{APPENDIX}

\section{Interview Protocol}

Table A1 lists the six interview questions used in this study.

\section{REFERENCES}

Adebayo, A. A., J. I. Onu, E. F. Adebayo, and S. O. Anyanwu, 2012: Farmers' awareness, vulnerability and adaptation to climate change in Adamawa State, Nigeria. Br. J. Arts Soc. Sci., 9, 104-115.

Adger, W. N., 2006: Fairness in Adaptation to Climate Change. MIT Press, $319 \mathrm{pp}$.

Adhikari, U., A. P. Nejadhashemi, and S. A. Woznicki, 2015: Climate change and eastern Africa: A review of impact on major crops. Food Energy Secur., 4, 110-132, https://doi.org/ 10.1002/fes3.61.

Agu, N. N., F. E. Ekpo, and U. O. Ajator, 2015: Assessment of key vulnerability sectors and adaptation strategies to climate change in Enugu State, Nigeria. Swift J. Res. Environ. Stud., $1(1), 001-007$.

Ajaero, C. K., T. I. Akukwe, and G. C. Asuoha, 2009: Climate change: Concepts and issues. Climate Change and the Nigerian Environment, R. N. C. Anyadike, I. A. Madu, and C. K. Ajaero, Eds., Jamoe Publishers, 1-17.

Ajaero, D. I., N. M. Okoro, and C. K. Ajaero, 2016: Perception of and attitude toward mass media reportage of the 2012 flood in rural Nigeria. SAGE Open, 6, 1-8, https://doi.org/10.1177/ 2158244016666887.

Akpoborie, T., 2012: Special report, 2012: A year of raging floods. West African Insight, accessed 22 March 2016.

Aliyu, A., 2018: NCF seeks multifaith approach to climate change, environmental challenge. DailyTrust, accessed 28 September 2018, https://www.dailytrust.com.ng/ncf-seeks-multifaith-approach-to-climate-change-environmental-challenge.html.

Apata, T. G., 2012: Effects of global change on Nigerian agriculture: An empirical analysis. CBN J. Appl. Stat., 2 (1), 31-50.

Arbuckle, G. J., and Coauthors, 2013: Climate change beliefs, concerns, and attitudes toward adaptation and mitigation 
among farmers in the midwestern United States. Climatic Change, 117, 943-950, https://doi.org/10.1007/s10584-0130707-6.

Ayanlade, A., and M. O. Jegede, 2016: Climate change education and knowledge among Nigerian university graduates. Wea. Climate Soc., 8, 465-473, https://doi.org/10.1175/WCAS-D-150071.1.

, M. Radeny, and J. F. Morton, 2017: Comparing small holder farmers' perception of climate change with meteorological data: A case study from southwestern Nigeria. Wea. Climate Extremes, 15, 24-33, https://doi.org/10.1016/j.wace.2016.12.001.

Babbie, E. R., 2011: The Basics of Social Research. Wadsworth, Engage Learning, $473 \mathrm{pp}$.

Bashir, M., 2014: Kogi after 2012 floods. Nation, accessed 29 December 2017, https://thenationonlineng.net/kogi-after2012-floods.

Beyers, J. L., 2004: Post fire seeding for erosion control: Effectiveness and impacts on native plant communities. Conserv. Biol., 18, 947-956, https://doi.org/10.1111/j.15231739.2004.00523.x.

Bharath, A. K., and R. J. Turner, 2009: Impact of climate change on skin cancer. J. Roy. Soc. Med., 102, 215-218, https://doi.org/ 10.1258/jrsm.2009.080261.

Binniyat, L., O. Ajayi, J. Erunke, and C. Ayansina, 2017: Southern Kaduna killings, FG, CAN, Catholic Church in war of words. Vanguard, 4 January 2017, accessed 14 April 2017, https:// www.vanguardngr.com/2017/01/southern-kaduna-killings-fgcan-catholic-church-war-words/.

BNRCC, 2011: A report of national adaptation strategy and plan of action on climate change for Nigeria. NASPA-CCN: Building Nigeria's Response to Climate Change Project, Federal Ministry of Environment Climate Change Department Rep., 101 pp., http:// csdevnet.org/wp-content/uploadNo.ATIONAL-ADAPTATIONSTRATEGY-AND-PLAN-OF-ACTION.pdf.

Bomberg, E., and A. Hague, 2018: Faith-based climate action in Christian congregations: Mobilisation and spiritual resources. Local Environ., 23, 582-596, https://doi.org/10.1080/ 13549839.2018.1449822.

Brown, D. A., 2001: The ethical dimensions of global environmental issues. Daedalus, 130 (4), 59-76.

Carr, W. A., 2010: The faithful skeptics: Conservative Christian religious beliefs and perceptions of climate change. M.S. thesis, Resource Conservation, College of Forestry and Conservation, University of Montana, $299 \mathrm{pp}$.

— M. Patterson, L. Yung, and D. Spencer, 2012: The faithful skeptics: Evangelical religious beliefs and perceptions of climate change. J. Study Religion Nat. Cult., 6 (3), https://doi.org/ 10.1558/jsrnc.v6i3.276.

CBCN, 2014: Church and state partnership in the provision of quality education. First Plenary Meeting of the Catholic Bishops' Conference of Nigeria, Sabon Lugbe, Abuja, Nigeria, CBCN, https://www.cben-ng.org/docs/g15.pdf.

_ 2017a: Bishop Dunia tasks government on healthcare delivery service. Catholic Bishops' Conference of Nigeria, accessed 4 April 2017, https://www.cbcn-ng.org/newsdetail.php?tab=253.

— 2017b: SECAM urged to be more pro-active on food sustainability. Catholic Bishops' Conference of Nigeria, accessed 14 April 2017, http://www.cbcn-ng.org/newsdetail.php?tab=618.

Chinowsky, P. C., A. E. Schweikert, N. L. Strzepek, and K. Strzepek, 2015: Infrastructure and climate change: A study of impacts and adaptations in Malawi, Mozambique, and Zambia. Climatic Change, 130, 49-62, https://doi.org/ 10.1007/s10584-014-1219-8.
Connolly-Boutin, L., and B. Smit, 2016: Climate change, food security, and livelihood in sub-Saharan Africa. Reg. Environ. Change, 16, 385-399, https://doi.org/10.1007/s10113-015-0761-x.

Corner, A., 2013: Christianity and climate change: The relationship between God and green. Guardian, 11 September 2013, accessed 25 March 2016, https://www.theguardian.com/sustainable-business/ blog/christianity-climate-change-sceptics-god-green.

Coward, H. G., and T. Hurka, Eds., 1993: Ethics and Climate Change: The Greenhouse Effect. Wilfred Laurier Press, 199 pp.

Djupe, P. A., and C. P. Gilbert, 2009: The Political Influence of Churches. Cambridge University Press, 284 pp.

, and P. K. Hunt, 2009: Beyond the Lynn White thesis: Congregational effects on environmental concern. J. Sci. Study Religion, 48, 670-686.

Ebele, N. E., and N. V. Emodi, 2016: Climate change and its impact in Nigerian economy. J. Sci. Res. Rep., 10 (6), 1-13, https:// doi.org/10.9734/JSRR/2016/25162.

Elum, Z. A., and J. B. Simonyan, 2016: Analysis of Nigerian insurers' perceptions of climate change. S. Afr. J. Econ. Manage. Sci., 19, 549-561, https://doi.org/10.4102/sajems.v19i4.1384.

Evangelical Climate Initiative, 2006: Climate change: An evangelical call to action. NPR, accessed 26 December 2018, https:/ www.npr.org/documents/2006/feb/evangelical/calltoaction.pdf.

Farauta, B. K., C. L. Egbule, A. E. Agwu, Y. L. Idrisa, and N. A. Onyekwuru, 2012: Farmers' adaptation initiatives to the impact of climate change on agriculture in northern Nigeria. J. Agric. Ext., 16, 132-144, https://doi.org/10.4314/jae.v16i1.13.

Fromming, U. U., and C. Reichel, 2012: Vulnerable coastal regions: Indigenous people under climate change. Religion in Environmental and Climate Change, D. Gerten and S. Bergmann, Eds., Bloomsbury Academic, 215-235.

Gerten, D., 2010: Adapting to climatic and hydrologic change: Variegated function of religion. Religion and Dangerous Environmental Change: A Transdisciplinary Perspective, S. Bergmann and D. Gerten, Eds., LIT, 39-56.

Gill, S. E., J. F. Handley, A. R. Ennos, and S. Pauleit, 2007: Adapting cities for climate change: The role of the green infrastructure. Built Environ., 33, 115-133, https://doi.org/10.2148/benv.33.1.115.

Guardian, 2015a: Adeboye empowers leaders for good governance. Guardian, 4 June 2015, accessed 13 April 2017, https:/guardian.ng/ features/greaterlagos/adeboye-empowers-leaders-for-goodgovernance/.

_- 2015b: Nigerian Catholics, others hold fast for climate change. Guardian, 22 February 2015, accessed 14 April 2017, https://guardian.ng/property/c25-property/nigerian-catholicsothers-hold-fast-for-climate-change/.

Gyssels, G., and J. Poesen, 2003: The importance of plant root characteristics in controlling concentrated flow erosion rates. Earth Surf. Processes Landforms, 28, 371-384, https://doi.org/ 10.1002/esp.447.

Hamin, E. M., and N. Gurran, 2009: Urban form and climate change: Balancing adaptation and mitigation in the U.S and Australia. Habitat Int., 33, 238-245, https://doi.org/10.1016/ j.habitatint.2008.10.005.

Holland, L., and J. S. Carter, 2005: Words v. deeds: A comparison of religious belief and environmental action. Sociol. Spectr., 25, 739-753, https://doi.org/10.1080/02732170500260908.

Ibekwe, N., 2012: Floods: Sad tale from affected states-ERA/FoEN. Premium Times, 9 October 2012, accessed 29 December 2017, https://www.premiumtimesng.com/news/103083-floods-sad-talefrom-affected-states-erafoen.html.

Idrisa, Y. L., B. O. Ogunbameni, A. A. Ibrahim, and D. B. Bawa, 2012: Analysis of awareness and adaptation to climate 
change among farmers in the Sahel Savannah agro-ecological zone of Borno State, Nigeria. Br. J. Environ. Climate Change, 2, 216-226, https://doi.org/10.9734/BJECC/2012/1475.

IPCC, 2014: Summary for policymakers. Climate Change 2014: Impacts, Adaptation, and Vulnerability. Part A: Global and Sectoral Aspects, C. B. Field et al., Eds., Cambridge University Press, 32 pp., https://www.ipcc.ch/site/assets/uploads/2018/02/ ar5_wgII_spm_en.pdf.

Ismail, N. A., 2014: Awareness, perception and understanding of climate change among the rural people of Okene, Nigeria. Confluence J. Environ. Stud., 9, 24-30.

Joshua, P., 2015: Catholic group prays for Nigeria, tasks leaders on good governance. Champions Newspapers.

Kaplan, M. S., 2010: Will religions guide us on our dangerous journey? Moral Ground: Ethical Action for a Planet in Peril, K. D. Moore and M. P. Nelson, Eds., Trinity University Press, 263-267.

Leadership, 2018: Nigeria and issues of climate change. Leadership, 2 December 2018, accessed 28 December 2018, https:// leadership.ng/2018/12/02/nigeria-and-issues-of-climate-change/.

Lujala, P., H. Lein, and J. K. Rod, 2015: Climate change, natural hazards, and risk perception: The role of proximity and personal experience. Local Enviro.: Int. J. Justice Sustainability, 20, 489-509, https://doi.org/10.1080/13549839. 2014.887666.

Madzwamuse, M., 2010: Climate governance in Africa-Adaptation strategies and institutions. Heinrich Boll Stiftung, https:// www.boell.de/en/ecology/africa-climate-governance-in-africaadaptation-strategies-and-institutions-10914.html.

Makinwa, S., 2016: Church offers free medicare. Guardian, 2 October 2016, accessed 14 April 2017, https:/guardian.ng/ sunday-magazine/ibru-ecumenical-centre/church-offers-freemedicare- $2 /$.

Masselink, G., and P. Russell, 2013: Impacts of climate change on coastal erosion. MCCIP Sci. Rev., 2013, 71-86, https://doi.org/ 10.14465/2013.arc09.071-086.

Mastaler, J. S., 2014: The role of Christian ethics, religious leaders, and people of faith at a time of ecological and climate crisis New Theology Rev., 26 (2), 43-48.

Millais, C., Ed., 2006: Common belief: Australia's faith communities on climate change. Climate Institute Doc., 40 pp., http:// www.climateinstitute.org.au/verve/_resources/commonbelief.pdf.

Miranda, J. D., C. Armas, F. M. Padilla, and F. I. Pugnaire, 2011: Climate change and rainfall patterns: Effects on semi-arid plant communities of the Iberian southeast. J. Arid Environ., 75, 1302-1309, https://doi.org/10.1016/ j.jaridenv.2011.04.022.

Moore, K. D., and M. Nelson, 2010: Introduction. Moral Ground: Ethical Action for a Planet in Peril, K. D. Moore and M. P. Nelson, Eds., Trinity University Press, $\mathrm{xv}-\mathrm{xxix}$.

Morrison, M., R. Duncan, and K. Parton, 2015: Religion does matter for climate change attitude and behavior. PLOS ONE, 10, 0134868, https://doi.org/10.1371/journal.pone.0134868.

Nasr, S. H., 1967: Man and Nature: The Spiritual Crisis in Modern Man. Kazi Publishers, 151 pp.

Nche, G. C., 2012: Challenges of climate change: The role of Christian religious leaders. J. Educ. Soc. Res., 10, 73-80.

— C. H. Achunike, A. Okoli, and B. C. Diara, 2017: Challenges of climate change and the culpability of churches: Towards an effective church climate change action in Nigeria. Missionalia, 45, 168-187, https://doi.org/10.7832/45-2-183.

NEST, 2011: Reports of research projects on impacts and adaptation. Building Nigeria's Response to Climate Change
Project Nigerian Environmental Study/Action Team Doc., $101 \mathrm{pp}$

— , and E. Woodley, 2012: Learning from experience-Communitybased adaptation to climate change in Nigeria. Building Nigeria's Response to Climate Change Project Nigerian Environmental Study/Action Team Doc., 66 pp., http://csdevnet.org/wp-content/ uploads/Learning-from-experiences.pdf.

Niang, I., and Coauthors, 2014: Africa. Climate Change 2014: Impacts, Adaptation, and Vulnerability, Part B: Regional Aspects, V. R. Barros et al., Eds., Cambridge University Press, 1199-1265, https://www.ipcc.ch/site/assets/uploads/2018/02/WGIIAR5Chap22_FINAL.pdf.

NPRC, 2010: Summary of research finding. Nigeria Pentacostal Centre Doc.

Nwaigbo, F., and Coauthors, Eds., 2011: Theology for sustainable ecology in Africa: The earth as God's gift. Proc. Conf. of the 22nd CIWA Theology Week, Port Harcourt, Nigeria, Catholic Institute of West Africa, 340 pp.

Nwankwo, N., 2015: 300 rural dwellers receive free medical care in FCT. Nigerian Pilot.

Nzeadibe, T. C., C. L. Egbule, N. A. Chukwuone, A. E. Agwu, and V. C. Agu, 2012: Indigenous innovations for climate change adaptation in the Niger Delta Region of Nigeria. Environ. Dev. Sustainability, 14, 901-914, https://doi.org/ 10.1007/s10668-012-9359-3.

Obasanjo, O., 2009: The Spread of Pentecostalism in Nigeria. Dominion, $263 \mathrm{pp}$.

Ofuoku, A. U., 2011: Rural farmers' perception of climate change in central agricultural zone of Delta State, Nigeria. Indones. J. Agric. Sci., 12 (2), 63-69, https://doi.org/10.21082/ ijas.v12n2.2011.p63-69.

Ojomo, E., M. Elliot, U. Amjad, and J. Bartram, 2015: Climate change preparedness: A knowledge and attitudes study in southern Nigeria. Environments, 2, 435-448, https://doi.org/ 10.3390/environments2040435.

Okonoboh, R., 2016: Prayer mountains: Solutions grounds or show centres? Nigerian Tribune, 10 July 2016, accessed 28 December 2017, https://tribuneonlineng.com/prayer-mountains-solutiongrounds-show-centres/.

Okpalike, C., and K. L. Nwadialor, 2015: The contributions of the Christian missionaries in building the Nigerian nation, 18401960. Acad. J. Interdiscip. Stud., 4 (2), 159-168, https://doi.org/ 10.5901/ajis.2015.v4n2p159.

Oluwabamide, A. J., and J. O. Umoh, 2011: An assessment of the relevance of religion to healthcare delivery in Nigeria: Case of Akwa-Ibom State. J. Sociol. Anthropol., 2 (1), 47-52, https:// doi.org/10.1080/09766634.2011.11885547.

Onah, N. G., and C. O. T. Ugwu, 2008: Prayer as a panacea for human problems: Nigerian Christian experience. Afr. J. Online, accessed 23 December 2017, https://www.ajol.info/ index.php/jrhr/article/view/87196/76939.

Onwuka, S. U., F. O. Ikekpeazu, and D. C. Onuoha, 2015: Assessment of the environmental effects of 2012 floods in Umuleri, Anambra East local government area of Anambra State, Nigeria. Int. Res. J. Nat. Sci., 3, 1-15.

Oruonye, E. D., 2011: An assessment of the level of awareness of the effects of climate change among students of tertiary institutions in Jalingo Metropolis, Taraba State Nigeria. J. Geogr. Reg. Plann., 4, 513-517.

Osijonwo, T., 2017: Prayer: A panacea to Nigeria's problem-Senator Ibikunle Amosun. Egba Diocese, accessed 23 December 2017, https://egbadiocese.org/2017/02/24/prayer-a-panacea-to-nigeriasproblem/. 
Oyedele, D., 2017: The dwindling lake. Development and Cooperation, accessed 28 December 2018, https://www.dandc.eu/en/article/ climate-change-lake-chad-region-affects-several-countriesnegatively.

Oyediran, M., 2017: Anglican Church protests alleged invasion of its educational institution by host community. Daily Times, 16 March 2017, accessed 14 April 2017, https://dailytimes.ng/2017/03/ 16/anglican-church-protests-alleged-invasion-educationalinstitution-host-community/.

Pepper, M., and R. Powell, 2013a: Environmental activities in local churches. NCLS Research Occasional Paper 20.

__, and —_, 2013b: Senior local church leaders' environmental views and actions. NCLS Research Occasional Paper 21, 7 pp.

—_, and R. Leonard, 2016: Climate change, politics and religion: Australian churchgoers' beliefs about climate change. Religions, 7, 47, https://doi.org/10.3390/rel7050047.

Pereira, L., 2017: Climate change impacts on agriculture across Africa. Oxford Research Encyclopedia of Environmental Science, Oxford University Press, https://doi.org/10.1093/ acrefore/9780199389414.013.292.

Pew Research Center, 2011: Global Christianity-A report on the size and distribution of the world's Christian population. Pew Research Center: Religion and Public Life, https:// www.pewforum.org/2011/12/19/global-christianity-exec/.

Pope Francis, 2015: Laudato Si': Encyclical Letter of the Holy Father Francis on Care for our Common Home. Paulines Publications Africa, $176 \mathrm{pp}$.

Posas, P. J., 2007: Roles of religion and ethics in addressing climate change. Ethics Sci. Environ. Polit., 9, 31-49, https://doi.org/ 10.3354/esep007031.

Prelli, L. J., and T. S. Winters, 2009: Rhetorical features of green evangelicalism. Environ. Commun., 3, 224-243, https://doi.org/ 10.1080/17524030902928785.

Romm, J., 2016: Climate Change: What Everyone Needs to Know. Oxford University Press, $328 \mathrm{pp}$.

Rudd, K., 2015: Paris can't be another Copenhagen. New York Times, accessed 6 April 2016, https://www.nytimes.com/2015/05/26/ opinion/kevin-rudd-paris-cant-be-another-copenhagen.html.

Sachdeva, S., 2016: Religious identity, beliefs, and views about climate change. Oxford Research Encyclopedia of Climate Science, Oxford University Press, https://doi.org/10.1093/acrefore/ 9780190228620.013 .335 .

Sanders, C., 2003: Application of Colaizzi's method: Interpretation of an auditable decision trail by a novice researcher. Contemp. Nurse J., 14, 292-302, https://doi.org/10.5172/conu.14.3.292.

Scott-Emuakpor, A., 2010: The evolution of healthcare system in Nigeria: Which way forward in the twenty-first century. Niger. Med. J., 51, 53-65.

Serdeczny, O., and Coauthors, 2016: Climate change impacts in sub-Saharan Africa: From physical changes to their social repercussions. Reg. Environ. Change, 17, 1585-1600, https:// doi.org/10.1007/s10113-015-0910-2.

Shehu, M. U., and S. Molyneux-Hodgson, 2014: Faith communities and environmental degradation in northeast Nigeria. Int. J. Environ. Sustainability, 10, 27-40, https://doi.org/10.18848/ 2325-1077/CGP/v10i01/59454.

Shosha, G. A., 2010: Employment of Colaizzi's strategy in descriptive phenomenology: A reflection of a researcher. Eur. Sci. J., 8 (27), 31-43.

Simkins, R. A., 2008a: An introduction: The legacy of Lynn White, Jr. Religion and the Environment, R. A. Simkins, Ed., Supplement 3, Journal of Religion \& Society, 1-4, https://dspace2.creighton.edu/xmlui/bitstream/handle/10504/ 64673/2008-10.pdf? sequence $=1$.

$\ldots, 2008 \mathrm{~b}$ : The end of nature: Humans and the natural world in the history of creation. Religion and the Environment, R. A. Simkins, Ed., Supplement 3, Journal of Religion \& Society, 47-65, https://dspace2.creighton.edu/xmlui/bitstream/handle/ 10504/64612/2008-13.pdf? sequence $=1$.

Singleton, R., and B. C. Straits, 1999: Approaches to Social Research. Oxford University Press, 618 pp.

Spence, A., W. Poortinga, C. Butler, and N. F. Pidgeon, 2011: Perceptions of climate change and willingness to save energy related to flood experience. Nat. Climate Change, 1, 46-49, https://doi.org/10.1038/nclimate1059.

Speziale, H. J., and D. R. Carpenter, 2007: Qualitative Research in Nursing: Advancing the Humanistic Imperative. 4th ed. Lippincott, Williams and Wilkins, $470 \mathrm{pp}$.

Stehr, N., and R. Grundmann, 2012: How does knowledge relate to political action? Innov. Eur. J. Soc. Sci. Res., 25 (1), 29-44, https://doi.org/10.1080/13511610.2012.655572.

Storrow, B., 2018: Global $\mathrm{CO}_{2}$ emissions rise after Paris Climate Agreement signed. Scientific American, accessed 7 April 2018, https://www.scientificamerican.com/article/global-co2-emissionsrise-after-paris-climate-agreement-signed/.

Stults, M., 2006: Religious groups becoming a factor in climate policy debate, $24 \mathrm{Feb} 2006$. Climate Institute.

Tarakeshwar, N., A. B. Swank, K. I. Pargament, and A. Mahoney, 2001: The sanctification of nature and theological conservatism: A study of opposing religious correlates of environmentalism. Rev. Relig. Res., 42, 387-404, https://doi.org/ 10.2307/3512131.

Taylor, R. B., 2009: Dark Green Religion: Nature Spirituality and the Planetary Future. University of California Press, 360 pp.

Thomas, D. S. G., and C. Twyman, 2005: Equity and justice in climate change adaptation amongst natural-resource-dependent societies. Global Environ. Change, 15, 115-124, https://doi.org/ 10.1016/j.gloenvcha.2004.10.001.

Thomas, L., 2013: Terrorism: Anglican Bishop urges more prayers. Vanguard, 24 November 2013, accessed 14 April 2017, https:// www.vanguardngr.com/2013/11/terrorism-anglican-bishopurges-prayers/.

Thomas-Odia, I., 2018: Interfaith groups create awareness on climate change. Guardian, 17 September 2018, accessed 28 December 2018, https:/guardian.ng/property/interfaith-groups-createawareness-on-climate-change/.

Truelove, H. B., and J. Joireman, 2009: Understanding the relationship between Christian orthodoxy and environmentalism: The mediating role of perceived environmental consequences. Environ. Behav., 41, 806-820, https://doi.org/ 10.1177/0013916508328905.

Tucker, M. E., 2003: Worldly Wonder: Religions Enter Their Ecological Phase. Open Court, 120 pp.

- and J. A. Grim, Eds., 2001: Religion and ecology: Can the climate change? Daedalus, 130, 1-306.

Ugwu, I., and O. G. Chukwuma, 2012: Prayer and national security: A study of Isaiah 58. Int. J. Theology Reformed Tradit., 4, 173-190.

U.K. Department for Environment, Food and Rural Affairs, 2012: Floods and coastal erosion. DEFRA Climate Change Risk Assessment Doc., 4 pp., accessed 21 December 2017, http://randd.defra.gov.uk/Document.aspx?Document= CCRASummaryFloodsandCoastalErosion.pdf.

U.S. Conference of Catholic Bishops, 2015: Caring for God's creation: Resources for liturgy, preaching, and taking 
action. Department of Justice, Peace and Human Dignity Doc., accessed 20 December 2017, http://www.usccb.org/ issues-and-action/human-life-and-dignity/environment/upload/ ecology-resource-all.pdf.

Veldman, R. G., A. Szasz, and R. Haluza-Delay, 2014: How the World's Religions Are Responding to Climate Change: Social Scientific Investigations. Routledge, 344 pp.

Whitmarsh, L., 2008: Are flood victims more concerned about climate change than other people? The role of direct experience in risk perception and behavioural response. J. Risk Res., 11, 351-374, https://doi.org/10.1080/13669870701552235.
Wilkinson, K. K., 2012: Between God and Green: How Evangelicals Are Cultivating a Middle Ground on Climate Change. Oxford University Press, $256 \mathrm{pp}$.

Williams, M., 2015: 8 Christian denominations with the most liberal views on the environment. Newsmax, 6 May 2015, accessed 20 December 2017, https://www.newsmax.com/ fastfeatures/christian-environment-liberal-church/2015/05/ 06/id/642846/.

Zuazo, V. H. D., and C. R. R. Pleguezuelo, 2009: Soil-erosion and runoff prevention by plant covers. Sustainable Agriculture, E. Lichtfouse et al., Eds., Springer, 785-811. 